\title{
OPERATING DIFFICULTIES OF SMALL WATER RESERVOIR LOCATED IN WASILKOW
}

\author{
Anna Siemieniuk' ${ }^{1}$ Joannna Szczykowska ${ }^{1}$, Józefa Wiater $^{1}$ \\ Department of Technology in Engineering and Environmental Protection, Faculty of Civil and Environmental \\ Engineering, Białystok University of Technology,Wiejska 45A, 15-351 Białystok, Poland, e-mail:j.szczykowska@ \\ gmail.com
}

Received: 2014.08.14

Accepted: 2014.10.17

Published: 2015.01.02

\begin{abstract}
When considering the issue of the functioning of small water reservoirs, the attempt to assess changes in trophy of small retention reservoir located in Wasilkow, Podlasie, before and after remediation, was carried out. Water samples tests were carried out once a month from April 2007 to March 2008, from April 2009 to March 2010 (before remediation), and from April 2013 to March 2014 (after removal of silt). Prior to works related to the reservoir remediation, a gradual increase in the number of tested contaminants and disturbances in the seasonal occurrence of nitrogen and phosphorus compounds were observed. Advanced eutrophic processes in Wasilków reservoir occur probably due to the supply of large amounts of humic and biogenic substances from the catchment, because a significant percentage of its area is covered by forests and agricultural lands. The development of the trophic status of the reservoir is largely influenced by the amount of phosphorus and total nitrogen supplied to the reservoir; the least affected by chlorophyll "a". Comparing the analyses performed in 2007/2008 and 2009/2010, a slight, but growing trend of average trophic levels of water in the basin Wasilków was found. Studies conducted in 2013/2014 revealed a significant decrease in the concentrations of all analyzed pollutants, and hence lower TSI values. It can be concluded that the reclamation associated with the removal of sediments brought the expected results.
\end{abstract}

Keywords: small retention reservoirs, contamination, biogenic compounds, trophy.

\section{INTRODUCTION}

Water retention is the capacity of a catchment to retain water. It depends on the terrain and covering vegetation, yet human activity is also very significant. Despite the good natural conditions, water retention and its storage can be very limited. In contrast, meeting the needs of all water users is based primarily on water storing in its proper quantity and quality.

River dams, as a result of artificial water damming, contribute to increased sedimentation of substances brought by the river into the storage reservoir. However, water retention in a reservoir is conducive to the intensity of metabolic processes, in particular, under conditions of excessive loads of phosphorus and nitrogen sup- plied to the reservoir [1]. Speaking of lake and reservoir resistance to pollution, the processes of self-purification and the capacity of the ecosystem, exhibiting as the decomposition of the influent contaminants are taken into account. It should be understood as the ability to precipitate the digested pollutants in sediments [2]. Then, in a very short period of time, the high trophic status of the ecosystem with all its consequences can be achieved. Appearing losses, deficits, and the total lack of oxygen in the bottom water layers make bottom sediments begin to release previously stored contaminants, which accelerate the degradation process $[3,4]$.

Considering the issue of the functioning of small water reservoirs, an attempt to assess trophy changes in a small retention reservoir located 
in Wasilkow, Podlasie, before and after remediation, was undertaken.

\section{MATERIAL AND METHODS}

Studies upon the changes in water trophy were carried out on small retention water reservoir located in Podlasie in Wasilkow on the river Supraśl.

The reservoir in Wasilkow was completed in 1968 , the volume of the waters contained is 150 thousand $\mathrm{m}^{3}$, and the surface of the reservoir is 12 hectares, while the catchment area supplying the reservoir is $1448.2 \mathrm{~km}^{2}$. The Supraśl river catchment above the water reservoir in Wasilkow is covered mainly by woodlands and to a lesser extent, the areas used for agricultural purposes. The lake was formed by the damming of river Supraśl for the water intake in Wasilkow. Maximum depth of the reservoir is $3 \mathrm{~m}$. Reservoir formerly served for recreational functions, but its water quality, bottom, and banks state deteriorated from year to year. Up to 2010 , the reservoir was gradually silting, the maximum thickness of sediments averaged $1.4 \mathrm{~m}$, the reservoir was also in $80 \%$ grown by emergent vegetation. Therefore, the reclamation was performed.

For many years, the community was looking for funds to cope with this problem. Half of the finances was allocated from the local funds, and the second half from The Regional Board for Melioration and Water Structures in Bialystok. About six hectares of overgrown land was cleared and more than 80 thousand cubic meters of sediments were transported. The de-silting cost was over 4 million PLZ.

Three measurement-control points were selected in the reservoir Wasilkow for testing - they were located within the inlet (first point) and outflow (third point) of river Supraśl, as well as in the central part of the reservoir (second point). The selection and placement of measurement and control points on the reservoir was dictated by the ability to capture the changes taking place in the study object. They were used to assess the trophic status of the tested waters. Collected waters were subject to the following determinations: total nitrogen, total phosphorus, and chlorophyll "a". Tests of water samples collected from the surface layer of the coastal zone, were carried out once a month from April 2007 to March 2008, from April 2009 to March 2010 (before remedia- tion), and from April 2013 to March 2014 (after de-silting the reservoir). All determinations were performed in accordance with current methodology [5].

The trophic state of Wasilków reservoir was also evaluated according to the concentration criteria and based on the calculated trophy indices TSI by Carlson and Kratzer and Brezonik. Trophy indices were calculated after Carlson trophic TSI (Chl) in $\mathrm{mg} / \mathrm{dm}^{3}$, TSI (TP) in $\mu \mathrm{g} / \mathrm{dm}^{3}$, according to Kratzer and Brezonika TSI (TN) in $\mathrm{mg} / \mathrm{dm}^{3}$ as well as the overall trophy of the reservoir TSI was determined using the mean value obtained from the three calculated indicators: TSI (Chl), TSI (TP), TSI (TN). The water transparency measured by Secchi disk was skipped, because it is of little importance in dam reservoirs, when assessing the trophic status. Water inflow during heavy rainfall brings a large amount of suspensions, which cause turbidity of retained water. The reduction in transparency due to this fact is not related to the development of phytoplankton $[6,7]$. The values of trophic status indicators to assess according to Carlson are as follows: TSI $<40-$ oligotrophy, 40-50 mesotrophy, 50-70 eutrophy, $>70$ hypertrophy [8]. The assessment of the eutrophication degree is made on the basis of average annual values biogenic indicators for flowing waters [9].

\section{RESULTS AND DISCUSSION}

The analyzes showed marked variability in the concentration of total nitrogen in individual years of research. Prior to works related to reservoir desilting, average annual total nitrogen concentrations ranged from 2.34 to $2.62 \mathrm{mg} \mathrm{N} / \mathrm{dm}^{3}$, while after the reclamation, this value decreased to 0.94 $\mathrm{mg} \mathrm{N} / \mathrm{dm}^{3}$. In 2007/2008 and 2009/2010, there was no clear seasonal changes in this indicator, instead a gradual increase in the average content of contaminants expressed in total nitrogen quantities, was monitored. Probably silts, from which nitrogen compounds could be released were the disturbing factor in such situation. River outwash was probably delivered in the form of humic substances along with waters of the Supraśl river, whose catchment is mostly wooded above the test reservoir. During the reservoir use, growth of the organic matter always occurs, and the lack of adequate amount of oxygen required for its rapid degradation leads to an excessive deposition of sediments on the bottom of the reservoir. This sit- 
uation favors oxygen deficiency, a condition for anaerobic processes that emit poisonous gases hydrogen sulfide and methane, toxic amines, and other degradation products of amino acids. When there is more sediment, the reservoir gets shallow and is converted into a muddy pond, which was the case in the Wasilków reservoir. Another factor that could affect the seasonality of nitrogen compounds occurrence could be their inflow from the catchment, that is of the forest-agriculture character. In 2013/2014, variations in the amount of total nitrogen: a decrease was observed in the summer time. It was affected by developing autotrophic organisms absorbing nitrogen compounds and building them into cell structure in spring and summer [10]. Undoubtedly, it was influenced by renewal of the system by removing silt from the reservoir bottom.

Similar results were achieved in the case of phosphorus, for which no clear seasonal changes in its concentration in the test water were recorded in 2007/2008 and 2009/2010. The average annual total phosphorus concentrations ranged from
0.99 to $1.22 \mathrm{mg} \mathrm{P} / \mathrm{dm}^{3}$. Also in this case, the reason may be the accelerated oxygen consumption in the reservoir waters by sediments accumulated at the bottom of the reservoir. Anaerobic conditions affect the release of phosphorus from bottom sediments into the water column. This may be an internal source of water enrichment in biogenic substances accumulated in the sediment. Reducing the amount of average annual total phosphorus to $0.27 \mathrm{mg} \mathrm{P} / \mathrm{dm}^{3}$ and seasonality of its incidence was observed in 2013/2014, which may indicate the restoration of the proper reservoir functioning.

When observing the content of chlorophyll "a" in waters of the reservoir Wasilków, regardless of the study years, seasonal variations in its content can be observed. The increase in the concentration of chlorophyll "a" is observed in spring, while in summer and fall, it slightly decreases to almost complete disappearance during winter. Average concentration of chlorophyll "a" in Wasilków reservoir ranged from 20.89 to $21.88 \mathrm{mg} / \mathrm{dm}^{3}$ during the study years before de-

Table 1. Waters testing results for reservoir Wasilków in 2007/2008

\begin{tabular}{|l|c|c|c|c|c|}
\hline \multicolumn{2}{|c|}{ Wasilków 2007/2008 } & First point & Second point & Third point & Mean value \\
\hline Tested parameter & Unit & $\frac{\text { min.-max }}{\text { mean }}$ & $\frac{\text { min.-max }}{\text { mean }}$ & $\frac{\text { min.-max }}{\text { mean }}$ & $\frac{\text { min.-max }}{\text { mean }}$ \\
\hline Total nitrogen & $\mathrm{mg} \cdot \mathrm{N} / \mathrm{dm}^{3}$ & $\frac{0.75-3.55}{2.15}$ & $\frac{0.82-3.85}{2.34}$ & $\frac{0.94-4.10}{2.52}$ & $\frac{0.84-3.83}{2.34}$ \\
\hline Total phosphorus & $\mathrm{mg} \cdot \mathrm{P} / \mathrm{dm}^{3}$ & $\frac{0.14-1.27}{0.70}$ & $\frac{0.21-1.83}{1.02}$ & $\frac{0.53-1.96}{1.24}$ & $\frac{0.29-1.69}{0.99}$ \\
\hline Chlorophyll „a" & $\mathrm{\mu g} / \mathrm{dm}^{3}$ & $\frac{12.24-24.5}{18.37}$ & $\frac{14.31-26.83}{20.57}$ & $\frac{16.9-30.54}{23.72}$ & $\frac{14.48-27.29}{20.89}$ \\
\hline
\end{tabular}

Table 2. Waters testing results for reservoir Wasilków in 2009/2010

\begin{tabular}{|l|c|c|c|c|c|}
\hline \multicolumn{2}{|c|}{ Wasilków 2009/2010 } & First point & Second point & Third point & Mean value \\
\hline Tested parameter & Unit & $\frac{\text { min. }-\max }{\text { mean }}$ & $\frac{\text { min. }- \text { max }}{\text { mean }}$ & $\frac{\text { min. }- \text { max }}{\text { mean }}$ & $\frac{\min .- \text { max }}{\text { mean }}$ \\
\hline Total nitrogen & \multirow{2}{*}{$\mathrm{mg} \cdot \mathrm{N} / \mathrm{dm}^{3}$} & $\frac{0.81-3.95}{2.38}$ & $\frac{0.89-4.25}{2.57}$ & $\frac{1.04-4.78}{2.91}$ & $\frac{0.91-4.33}{2.62}$ \\
\hline Total phosphorus & $\mathrm{mg} \cdot \mathrm{P} / \mathrm{dm}^{3}$ & $\frac{0.19-1.79}{0.99}$ & $\frac{0.29-2.03}{1.16}$ & $\frac{0.58-2.46}{1.52}$ & $\frac{0.35-2.09}{1.22}$ \\
\hline Chlorophyll „a" & $\mu \mathrm{g} / \mathrm{dm}^{3}$ & $\frac{14.04-26.1}{18.57}$ & $\frac{14.98-27.03}{21.01}$ & $\frac{17.1-32.00}{24.55}$ & $\frac{15.37-28.38}{21.88}$ \\
\hline
\end{tabular}

Table 3. Waters testing results for reservoir Wasilków in 2013/2014

\begin{tabular}{|l|c|c|c|c|c|}
\hline \multicolumn{2}{|c|}{ Wasilków 2013/2014 } & First point & Second point & Third point & Mean value \\
\hline \multicolumn{1}{|c|}{ Tested parameter } & Unit & $\frac{\text { Min. - max }}{\text { mean }}$ & $\frac{\text { Min. }- \text { max }}{\text { mean }}$ & $\frac{\text { Min. }- \text { max }}{\text { mean }}$ & $\frac{\text { Min. }- \text { max }}{\text { mean }}$ \\
\hline Total nitrogen & $\mathrm{mg} \cdot \mathrm{N} / \mathrm{dm}^{3}$ & $\frac{0.01-1.25}{0.63}$ & $\frac{0.19-1.85}{1.02}$ & $\frac{0.21-2.08}{1.15}$ & $\frac{0.14-1.73}{0.94}$ \\
\hline Total phosphorus & $\mathrm{mg} \cdot \mathrm{P} / \mathrm{dm}^{3}$ & $\frac{0.01-0.42}{0.21}$ & $\frac{0.02-0.53}{0.28}$ & $\frac{0.03-0.60}{0.32}$ & $\frac{0.02-0.52}{0.27}$ \\
\hline Chlorophyll „a" & $\mathrm{\mu g} / \mathrm{dm}^{3}$ & $\frac{1.04-2.14}{1.59}$ & $\frac{1.98-3.03}{2.51}$ & $\frac{2.01-3.30}{2.66}$ & $\frac{1.68-2.82}{2.25}$ \\
\hline
\end{tabular}


silting of the reservoir, to $2.25 \mathrm{mg} / \mathrm{dm}^{3}$ after its reclamation.

The study also evaluated the trophic status of Wasilków reservoir: the overall trophic level in years preceding the reclamation of the reservoir ranged from 76.92 to 78.62 and on that grounds, it could be ranked among the hypertrophic, while the overall TSI decreased to 58.98 in the last year of the research, qualifying it to eutrophic one.

Comparing the analysis performed in $2007 / 2008$ with those in $2009 / 2010$, a slight, but growing trend in average trophy levels of water was found in Wasilków reservoir. In the studies carried out in $2013 / 2014$, a significant decrease in the concentrations of all the studied pollutants, and hence lower TSI values, can be seen. It can be concluded that the reclamation associated with the removal of sediments brought the expected results.

The development of the trophic status of the reservoir is largely affected by the amount of total phosphorus delivered to the water. Also, higher concentrations of total nitrogen have impact on the growth of the reservoir fertility. Chlorophyll "a" had the least effect on the poor trophy status. A reduced amount of biogenic compounds in the waters of reservoir Wasilków is currently observed. Unfortunately, despite the diminished quantities of biogenic substances and chlorophyll "a" in waters of the reservoir, a high trophy degree of its waters was recorded in the last years of the study.

Advanced eutrophication processes in reservoir Wasilków occur probably due to the supply of large amounts of humic and biogenic substances from the catchment, because a significant percentage of its area is covered by forests and agricultural lands. Organic compounds inflowing from these areas will be subject to biodegradation, and their intensive decomposition will occur in the water column. Some compounds present in the form of suspensions will accumulate at the bottom, forming bottom sediments. And again, after many years of use, the accumulation of large amounts of outwashes containing a variety of organic compounds, will take place, and they will be subject to chemical, biochemical, and biological transformations.

In addition, water quality in the reservoir may be worsen by not entirely ordered wastewater management in the catchment. Bringing mineral compounds of phosphorus and nitrogen into the reservoirs, accelerates the natural aging and, in extreme cases, a rapid degradation [11], which undoubtedly was the case in Wasilkow reservoir.

From the user's point of view, it is desirable that reservoirs accumulated waters of good quality and stable physicochemical properties as a result of reclamation processes, or the new aqueous environment was characterized by high capacity for regeneration. Concentration of municipal, industrial, and transport pollution sources determines that as a rule, quality of water in such objects, often shallow, with a small area, so the small capacity, is unsatisfactory. In addition, such condition can worsen the runoff from the catchment of both humic and biogenic substances. However, despite this, and despite the high costs, a lot of benefits can be found. Reclamation of small water reservoirs seems to be worth considering, against keeping them in a form of degraded wastelands.

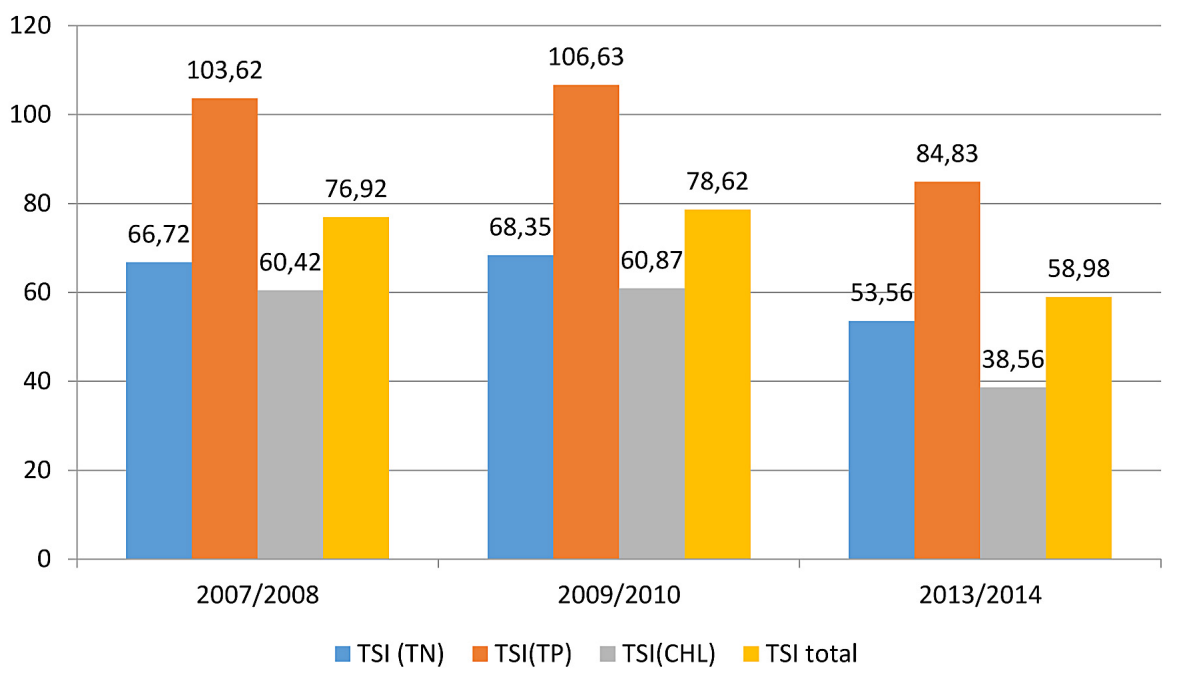

Figure 1. The annual average trophy level in Wasilków reservoir in particular years of the research 


\section{CONCLUSIONS}

1. Before reclamation of the reservoir, a gradual increase in the examined pollution indicators and disturbances in the seasonal occurrence of nitrogen and phosphorus compounds was observed.

2. Advanced eutrophication processes in Wasilków reservoir occur probably due to supply of large amounts of humic and biogenic substances from the catchment, because a significant percentage of its area is covered by forests and agricultural lands.

3. Development of the trophic status of the reservoir is largely affected by the amount of total phosphorus and nitrogen supplied to the water, chlorophyll ,a" had a weaker impact.

4. Reclamation of the reservoir associated with the removal of silt, brought the expected results, including a change of the reservoir trophy.

\section{REFERENCES}

1. Dunalska J. 2001. Effect of limited hypolimnetic with drawal on the content of nitrogen and phosphorus in the waters of Kortowskie Lake. Natural Sciences, 9, 333-346.

2. Ripl W., Wolter K.-D. 2005. The assault on the quality and value of lakes. [In:] O'Sullivan P.E. \&
Reynolda C.S. (eds.) The lakes handbook. Volume 2. Part I - General Issues. Chapter 2. Blackwell, Oxford, 25-61.

3. Mientki Cz. 1986. Wpływ usuwania wód hipilimionu na układy termiczne i tlenowe oraz zawartość związków azotu i fosforu w wodzie Jeziora Kortowskiego. Acta Acad. Agricult. Tech. Olst. Suppl. A 14, 1-53.

4. Nurnberg G.K. 1995. Quantifyinganoxia in lakes. Limnol. Oceanogr. 40, 100.

5. Hermanowicz W. et al. 1999. Fizyczno-chemiczne badanie wody i ścieków. Wydawnictwo Arkady, Warszawa.

6. Szczykowska J., Siemieniuk A., Wiater J. 2013. Sezonowe zmiany stanu troficznego zbiorników retencyjnych. Ekonomia i Środowisko, 2, 107-116.

7. Szczykowska J., Siemieniuk A., Wiater J. 2013. Problemy ekologiczne zbiorników małej retencji na Podlasiu. Ekonomia i Środowisko, 4, 234-244.

8. Carlson R.E. 1977. A tropic state index for lakes. Limnology and Oceanography, 22.

9. Rozporządzenie Ministra Środowiska z dnia 23 grudnia 2002 r. w sprawie kryteriów wyznaczania wód wrażliwych na zanieczyszczenia związkami azotu ze źródeł rolniczych. Dz. U. 2002 r. Nr 241 poz. 2093.

10. Kajak Z. 2001. Hydrobiologia - Limnologia. Ekosystemy wód śródlądowych. Wydawnictwo PWN, Warszawa.

11. Bartsch A.F. 1972. Role of phosphorus in eutrofication. EPA-R3-1972. 